TITLE:

\title{
Ultrasound exposure enhances the biological action of interferon in the liver(Abstract_要旨)
}

$\operatorname{AUTHOR}(S)$ :

Matsumura, Takeshi

\section{CITATION:}

Matsumura, Takeshi. Ultrasound exposure enhances the biological action of interferon in the liver. 京都大学, 2002, 博士(医学)

\section{ISSUE DATE:}

2002-03-25

URL:

http://hdl.handle.net/2433/149731

RIGHT: 


\begin{abstract}
氏
学位 (専攻分野)

学位記番号

学位授与の日付

学位授与の要件

研究科・専攻

学位論文題目
\end{abstract}

論文調査委員
阷哲村挍

博士（医学）

医 博 第 2501 号

平成 14 年 3 月 25 日

学位規則第 4 条第 1 項該当

医学研究科内科系専攻

Ultrasound exposure enhances the biological action of interferon in the liver

（超音波照射が肝に扔けるインターフェロンの生物学的活性を増強する）

(主查) 乾賢一教授山岡義生教授千葉勉

\section{論文内容 の 要旨}

[緒言] 近年，ウイルス性肝炎の治療薬としてインターフェロン（IFN）が用いられているが，その治療効果は必ずしも 十分とはいえない。IFN の投与量を増やせば治療効果を高めることが出来るが，その一方で副作用が増す。したがって， 全身に投与したIFN の活性を肝臟においてのみ増強させることが出来れば, ウイルス性肝炎の理想的な治療となる可能性 がある。近年, 超音波照射が, その照射領域に扔ける抗がん刻, 血栓溶解剂等の薬理効果を高めるという報告がなされてい る。そこで, IFNの肝臟における生物学的活性が, 肝㵴への超音波照射によって増強できるか否かをマウスを用いて検討 した。

[方法］IFNをBALB/c マウスの尾静脈より投与した後, 経皮的に肝臓に超音波照射を行った。超音波照射装置は, 一 般に臨床で使用されている超音波診断装置を用いた。IFN 投与24時間後にマウスを屠殺し，IFNによって誘道される酵素 である2，5'-オリゴアデニル酸合成酵素（2-5AS）の肝臓に抢けるレベルをウエスタンブロット法にて評価した。IFN 投与量ならびに超音波照射条件（超音波照射時間, 照射タイミングなど) を変化させ, これらの肝臟における2-5AS 誘導 に与える影響について検討した。また， ${ }^{125}$ Iで標識したIFNを用いて，IFNの体内動態㧍よび超音波照射がこれに与える 影響についても検討した。

[結果] 肝臓における2-5AS 誘導は IFN の投与量に依存して増加した。さらに, 超音波照射によって2-5AS 誘導はよ り増強された。肝臟の 2-5AS 誘導は超音波照射時間が30秒間までは増強されたが, より長い時間の超音波照射では逆に減 弱した。2-5AS 誘導に対する超音波照射のタイミングに関しては，IFN 投与30分後に拀ける超音波照射が最も有効であっ

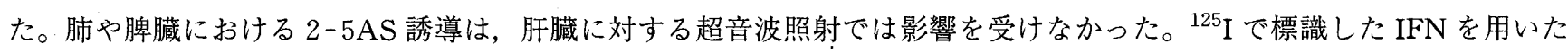
IFNの体内動態の検討では，IFNの肝集積性は超音波照射により影響されなかった。

[考察] IFN 投与後の肝臟に対し超音波照射を行うと, 肝㵴における2-5AS 誘導の増強を認めた。これは, 超音波照射 によるIFN の肝臓への集積性の向上や超音波照射によるIFN 自身の賦活化などによるものではなく, 超音波自身の作用, 例えば超音波により発生したマイクロストリーミングによるIFN の肝細胞表面レセプター周辺への移行性の増大などが原 因であると考えられた。これに対して，超音波照射のパワーが強すぎると，逆にIFN 自身に損傷などをおこし，2-5AS 誘 導を減少させる可能性があると考えられた。ウイルス性肝炎の治療として IFN を投与する際に肝臓への超音波照射を併用 すれば，全身性の副作用を増すことなく，肝臓におけるIFN の作用である抗ウイルス活性を増強できる可能性がある。こ の超音波照射による IFN 活性の増強法は，臨床応用が望まれる技術である。

\section{論文審査の結果 の要旨}

近年, ウイルス性肝炎の治療薬としてインターフェロン（IFN）が用いられているが，その治療効果は必ずしも十分とは 言えない。全身に投与したIFN の活性を肝臓においてのみ増強させることが出来れば, 治療効果を高め, 副作用を減じる 
ことができ，理想的な治療となる可能性がある。近年，超音波照射が，薬剤の薬理効果を高めるという報告がなされている。 そこで，申請者らは，IFN の生物活性が，肝臟への超音波照射によって増強できるか否かを検討した。

IFNをマウス尾静脈より全身投与した後, 臨床で使用されている超音波診断装置にて, 経皮的に肝臓に超音波照射を行 った。その後，マウスを屠殺し，IFNによって誘導される2'，5－オリゴアデニル酸合成酵素（2-5AS）の肝臓での発現を ウエスタンブロット法にて評価した。

IFN 投与後肝臓に超音波照射を行うと，2-5AS 誘導の増強を認めた。2-5AS 誘導量は超音波照射時間が30秒間までは増 強されたが，その後減少した。超音波照射のタイミングに関しては，投与30分後における照射が最も有効であった。超音波 照射によって肝臟での IFN の生物活性が増強したのは，超音波自身の作用，例えば超音波により発生したマイクロストリ ーミングによるIFN の肝細胞表面レセプター周辺への移行性の増大などが原因であると考えられた。以上，ウイルス性肝 炎の治療として IFNを投与する際に肝臓への超音波照射を併用すれば，肝臟における IFN の作用を增強できる可能性が示 された。

以上の研究は, 新しいウイルス性肝炎の治療法の開発に貢献し, 消化器病態学の発展に寄与するところが多い。 したがって，本論文は博士 (医学)の学位論文として価値あるものと認める。 なお，本学位授与申請者は，平成14年 3 月 7 日実施の論文内容とそれに関した試問を受け，合格と認められたものである。 